\title{
Georgia Tax Policy Directions in Value Added Tax (VAT) and Expected Results of Reforms
}

Iza BUKIA: PhD in Economics University of Georgia, Georgia.

\begin{abstract}
The research aims to review the direction of Georgia's economic policy, in particular, the reforms implemented in the field of tax policy in value added tax (VAT). For this purpose, the method of comparing the legislative records, as well as the analysis of official statistical data and their generalization are used, as well as the research I conducted (the results of a survey of entrepreneurs) on several reforms in value added tax. The current result of the major reforms in this tax is an indicator of positive dynamics. This study will allow stakeholders (as well as entrepreneurs) to evaluate the effectiveness of tax policy, which is reflected in both statistical information and international rankings. The general business environment following the reforms and the regulatory norms of value added $\operatorname{tax}(V A T)$ in Georgia will be analyzed. This will be the basis for observing the dynamics of the positive indicators of the reforms carried out, and at the same time to take into account the influence of environmental factors during the assessment.
\end{abstract}

Key words: Value added tax (VAT), Tax reform, Entrepreneurship, Economic policy, Tax policy, Value added tax (VAT) Fraud, Georgia.

JEL Classification: H2; H25; L26; K34; E62.

\section{Introduction}

The COVID 19 pandemic has had a negative impact on the world economy, and the Georgian economy was no exception. The current situation has a direct impact on the development of the business environment. This situation makes forecasts of economic recovery and development difficult to predict. Given the current situation, it is very important to pursue an economic policy that will have a positive impact on entrepreneurs. Given the current situation, Georgia has developed tax reforms and incentives to encourage entrepreneurs to overcome the negative impact of the pandemic relatively easily. This article will discuss the direction of tax reforms, which refers directly to value added tax (VAT) payers.

The most important of the taxes in Georgia is value added tax (VAT), which ranks first in taxes in budget revenues. Consequently, any legislative changes or new projects that are directly or indirectly related to a given tax have a particular impact on the budget and its revenue in terms of taxes. Therefore, it is interesting to review the draft law, which came into force on January 1 of the current year, which deals with value added tax (VAT). This change was conditioned by the Association Agreement between Georgia and the European Union, which provided for the harmonization of the VAT legislation in force with the EU legislation. Based on of this draft law, the tax legislation on VAT and the basic principles of this tax have been fundamentally changed in Georgia. Several important VAT reforms have also been implemented, which we will review below.

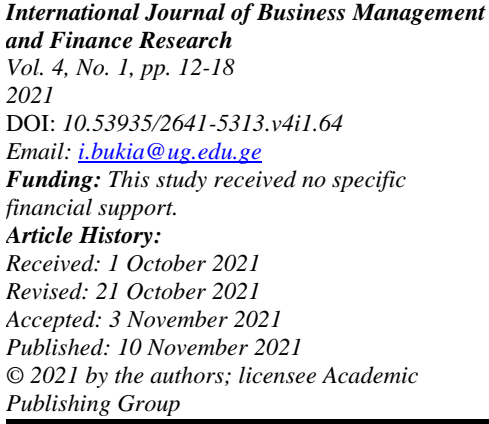




\section{Basic Overview}

A brief legislative excursion around the key tax reform related to value added tax (VAT) reform, the basic principles of pre-existing VAT and the legislation in force since 2021, we will see the following key differences: First of all, who is a person paying VAT, according to the current legislation, it is any person who independently carries out any kind of economic activity in any place, regardless of the purpose and result of this activity (Parliament of Georgia, 2010). Under the legislation in force until 2021, VAT payers were differentiated into seven different types, namely: A) a person registered as a VAT payer; B) a person who is obliged to register as a VAT payer; C) a person who imports or temporarily imports goods into Georgia, only for this import or temporary import, without the obligation to register; D) a non-resident (except for a natural person who is a citizen of Georgia), who provides services without registration as a VAT payer in Georgia and a permanent establishment of a non-resident registered for tax purposes in Georgia, only for this service and is subject to reverse charge; E) a person who, within the framework of a measure for securing the fulfillment of a contractual obligation, transfers the subject matter of the claim (goods) to the creditor only for this transaction and is subject to reverse charge, without the obligation of registration; F) a person whose goods are sold within the framework of a measure to secure the payment of tax arrears or for the purpose of repaying other monetary obligations (other than sanctions imposed by criminal and administrative rules) by auction, direct sale or otherwise, only for this operation, without obligation to register; G) a person whose custodial property is sold in accordance with the Law of Georgia on Insolvency Proceedings, only for this transaction, without the obligation to register (Parliament of Georgia, 2010). In case of VAT taxable transactions, the current legislation stipulates: A) supply of goods by a taxable person on the territory of Georgia in exchange for remuneration within the framework of economic activity; B) the provision of services by a taxable person in the territory of Georgia in exchange for remuneration within the framework of economic activity; C) Import of goods (Parliament of Georgia, 2010). As for the list of VAT taxable transactions before the change, it was very broken down and detailed, which also included VAT taxation facilities (A) a taxable transaction; B) import; C) export, re-export; D) Temporary importation. Parliament of Georgia (2010), and taxable transactions included the following (which in turn was also concretized in different cases): A) supply of goods and / or services within the framework of economic activity on the territory of Georgia; B) use of goods / services purchased with VAT for non-economic activities (except for the case of free delivery of goods and / or services free of charge to a state and / or municipality by a legal entity under public law), if the taxpayer has received VAT deduction for these goods / services; C) in case of cancellation of registration as a VAT payer, the balance of goods on which the payer has received a VAT deduction; D) Use as a fixed asset an own production building; E) Acquisition of services or goods from the enterprise and / or partnership in exchange for a share in individual ownership (in this case the removal and / or registration of property is considered as delivery of property by the partnership); F) return of fixed assets to the lessor by the lessee upon expiration or early termination of the lease agreement; G) moment of revocation of the status at the expiration or early termination of the status of a tourist enterprise (Parliament of Georgia, 2010). It is noteworthy that under the legislation in force until 2021, the VAT taxable transaction was a temporary import, which is no longer a taxable transaction under current legislation, this change makes it much easier for entrepreneurs to operate, who used the given service. Such operations included, for example, the leasing of equipment by a construction company from a non-resident. This operation was considered a temporary importation and was consequently taxed with VAT. According to the current legislation, this transaction is no longer included in the list of taxable transactions. The above differences concerned only the definition of a VAT payer and VAT taxable transactions. Naturally, there are changes in the VAT legislation in other directions as well, the existing legal records around it are very extensive and detailed, which naturally includes determining the amount, time and place of VAT taxable transaction, as well as other regulatory rules around a given tax. Which complicates the detailed discussion of legislative changes in a given format. However, there are a number of directions that have not changed substantially, for example: VAT rate (18\%), Its mandatory registration requirements (From the date of exceeding the total amount of GEL 100,000 taxable goods supply / service transactions performed by a taxable person during any continuous 12 calendar months, who must apply to the tax authority no later than 2 working days for registration as a VAT payer) and grounds for deregistration. However, there is some change in taxable transactions, which determines a turnover of 100,000 in VAT. It should also be noted that

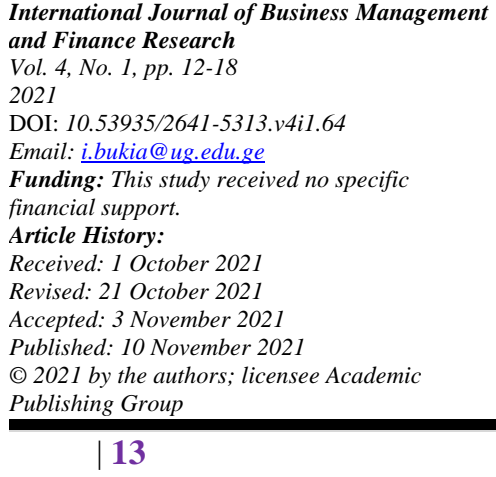


unlike the current version of VAT until 2021, definitions of terms specifically for VAT purposes have been added to this legislative package and added a new taxable transaction - voucher transactions.

The main essence of this tax reform is to support the integration processes with the EU and to bring it closer to the EU VAT Directive. Therefore, amendments were made to the Tax Code of Georgia and the VAT regulatory provisions were formulated in a new edition. This reform has been implemented based on approaches of international best practice, which aims to improve the investment environment, reduce disputes and simplify the fulfillment of tax obligations. To summarize the main directions of the reform, it is as follows: The list of services that are not taxed outside of Georgia is expanding. More specifically, in basic cases it is considered as a place of service where the recipient of the service (taxable person) is based; Expands and clarifies transactions exempt from VAT related to the transportation of goods; Temporary importation of goods is no longer considered a taxable transaction; In addition to medical and educational activities, the supply of services and goods directly related to and auxiliary related to it is exempt from taxation; Medical educational and separate social activities will not be taxed by the organization in order to raise funds; Will not be taxed on the delivery of a sample of goods or a gift of small value; Regulations related to VAT taxation of free delivery of goods are simplified; Natural person paying VAT will no longer be restricted from accounting by cash method (Revenue Service of Georgia, 2020).

However, it is also noteworthy to note the fact that tax legislative changes in general have a somewhat difficult impact on business, and this is especially the case when it comes to the most important tax. An example of this is one of the tax legislative changes related to the addition of VAT taxable transaction, which was implemented in 2017. It concerned the determination of the time of VAT on one of the transactions, in particular, the determination of the time of taxation of the amounts received in advance with VAT. The reform given by the entrepreneurs surveyed was rated as the most negatively impacted reform for business. The above research, which was conducted by me (the research was conducted in 2019), was related to tax reforms and their impact on business and entrepreneurship. The study included an assessment of the satisfaction of entrepreneurs with the various tax reforms and the impact of these tax reforms on business, which revealed both positive and negative tax reforms. It is the tax reform carried out within the framework of VAT, which added to the VAT taxable transaction - determination of the time of taxation of advances, had the most negative impact on the activities of entrepreneurs, where the percentage distribution of opponents of this reform was $61 \%$. As expected, the given legislative reform caused a pronounced dissatisfaction on the part of entrepreneurs. In this case, the given change with the right approach was distinguished in the context of several specific activities (e.g. in the context of the construction sector), however, since the existing reform has been extended to all taxpayers of full value added tax (VAT) regardless of the type of activity, it was naturally assessed negatively by the surveyed entrepreneurs. It is important to optimally determine the time of each VAT object / operation and taxation, as there is no impediment and no extra barrier for the entrepreneur. However, on the other hand, also a significant reform that has affected the given tax is the system of automatic return of overpaid amounts in value added tax (VAT), which was launched for entrepreneurs on February 15, 2019. The given reform is important in the sense that taxpayers who have certain amounts of excess in the given tax they can be returned within 24 hours without any bureaucratic procedures, which simplifies the relationship for entrepreneurs with the Revenue Service, both in terms of time and simplicity of procedures, and naturally, it has a positive impact on their activities, which is also confirmed by the evaluations of the entrepreneurs participating in the study. These two simple examples also show how important each component is in the implementation of tax reform, especially since it relates to the most influential tax in terms of budget revenues (Bukia, 2019).

It is the VAT refund system designed to support the economy and business, through which the refund surplus calculated by the automatic refund program, is automatically reflected in the personal bank account of the taxpayer, without any additional request, has become one of the most positively impacted tax reform and simplification. In 2020, using the automatic VAT refund program, more than one billion GEL was returned, which is 466 million GEL. In GEL more than the amount of VAT was refunded in 2019. This amount was returned to the business / entrepreneurs in a simplified manner, which is a huge boost in the event of a pandemic. Information on this tax reform was also shared with international partners at the 13th plenary meeting of the Organization for Economic Co-operation and Development (OECD) Tax Administration Forum (FTA). The plenary session was attended by more than 50 heads of tax administrations around the world and more than 300 delegates, including representatives of international organizations and the business

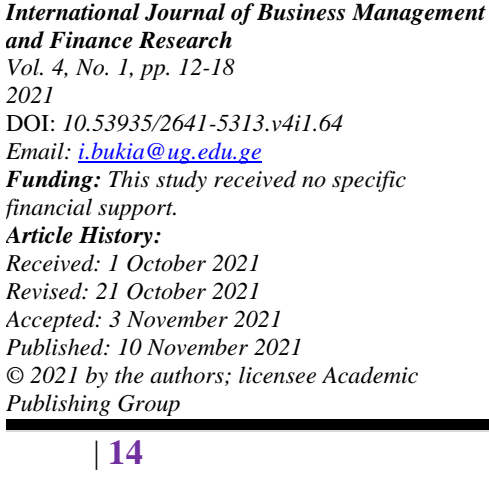


sector. At the plenary meeting, Georgia's experience was shared with the Revenue Service in support of the government during the Covid-Pandemic period and related challenges (For the plenary meeting, a video presentation was prepared by the Revenue Service on the automatic VAT refund program. This video presentation was posted on the OECD FTA website and the OECD YouTube channel) (Revenue Service of Georgia, 2020).

Also, a significant reform has been implemented in the field of value added tax (VAT) this year, which refers to a new mechanism for registration as a VAT payer, this is "the status of a qualified VAT payer", which aims to improve the tax administration process, manage the risks of fraudulent schemes, as well as reduce VAT registration and illegal issuance of relevant documents. Through this mechanism, certain criteria are selected, after which the taxpayer is granted the status of a qualified VAT or non-qualified VAT payer. The given criteria are as follows:

- A person newly registered as a VAT payer shall be considered an unqualified VAT payer from the moment of registration as a VAT payer.

- A person with the status of a qualified VAT payer shall be automatically revoked the status of a qualified VAT payer and granted the status of an unqualified VAT payer no later than the 15th day of the month following the relevant month, through a special program. If he / she does not have a transaction on the personal taxpayer's registration card during any 12 consecutive calendar months (In this case, no transaction is taken into account, according to which the amount spent on the personal taxpayer's registration card is equal to 0 ).

- A person with the status of a qualified VAT payer will be automatically revoked the status of a qualified VAT payer through a special program and granted the status of an unqualified VAT payer if he / she is not registered with a valid bank account number according to the information in the Revenue Service.

- A person with the status of a qualified VAT payer with a recognized tax debt as defined by a tax authority will have his / her status as a qualified VAT payer revoked and granted the status of an unqualified VAT payer.

- For an unqualified VAT payer, the decision to grant or refuse the status of a qualified VAT payer is made by an authorized person of the tax authority (including in case of an application by an interested person), under the rules established by the Head of the Revenue Service.

- The restriction specified in Article 563, Paragraph 1, Subparagraph "c" of the Instruction approved by the Order №996 of the Minister of Finance of Georgia “On Tax Administration” of 31 December 2010 (based on the order of the Head of the Revenue Service and according to the methodology approved by him. Decree N996) The restriction will apply to a person registered as a VAT payer In case of granting the status of unqualified VAT payer, during the period of validity of the mentioned status.

- For the reporting period or issue on which the tax authority has carried out the tax audit or accrual, the program should be limited to the issuance of the tax invoice / tax document in the above period / periods. This is allowed in case the taxpayer submits an application to the Revenue Service and the relevant arguments, which will be examined by the Audit Department and no later than 3 working days after the relevant decision is made, the taxpayer will be allowed to issue the relevant tax invoice / tax document by the rules established by the Minister of Finance of Georgia.

- Subscription of the given documents is allowed in case of application by the taxpayer to the Revenue Service and submission of relevant documents, which will be reviewed by the Debt Management Department and no later than 3 working days after the relevant decision is made, the taxpayer will be allowed to issue the relevant consignment note, tax invoice by the rules established by the Ministry of Finance of Georgia (2021).

This mechanism is one of the levers to prevent VAT fraud, which is a key tax problem in both Georgia and European countries in terms of VAT. In 2018, the VAT Gap in the EU was $€ 140$ billion, equating to a total revenue loss across the EU of $11 \%$. The 2020 year's report also forecasts a potential increase in VAT revenue losses in 2020 due to the effects of the coronavirus pandemic on the global economy. The loss is forecast to be $€ 164$ billion in 2020 (European Commission, 2020). As Paolo Gentiloni, Commissioner for Economy (European Commission) points out - "Today's figures show that efforts to shut down opportunities for VAT fraud and evasion have been making gradual progress - but also that much more work is needed. The coronavirus pandemic has drastically altered the EU's economic outlook and is set to deal a serious blow to VAT revenues too. At this time more than ever, EU countries simply cannot afford such losses. That's why

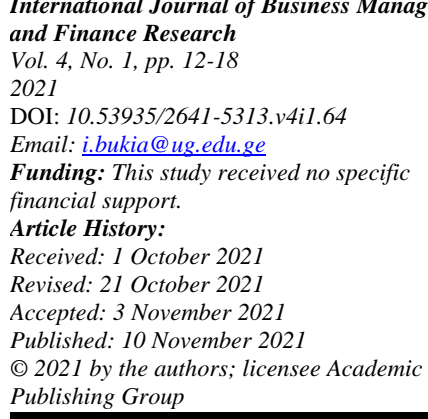


we need to do more to step up the fight against VAT fraud with renewed determination, while also simplifying procedures and improving cross-border cooperation."

In order for the newly adopted legislative changes to be properly understood by taxpayers and therefore to properly tax their transactions and, most importantly, to have a positive impact on their entrepreneurial activities, It is important to understand each taxable transaction correctly and not simply aligned with the EU legislation, regardless of the peculiarities of the regional mark. It is also noteworthy that the introduction of the existing changes coincided with the Covid Pandemic, which further complicated the economic situation and business activities both in Georgia and around the world. If we also take into account that a number of preferential actions were taken by the state in order to maintain business during the given period, This makes it much more difficult to try to determine the real outcome of a given reform study. To look at the dynamics of value added tax (VAT) by years and at the same time take into account the two years of the Covid pandemic, we get the following picture (see Figure N1), where the dynamics of a given tax can be seen clearly, In particular, the amounts included in the budget in terms of VAT were characterized by an upward trend, although the first year of the Covid Pandemic (2020) naturally received less from this tax in the budget than in 2019, although it was higher than in 2018. However, the data of the current year gives a promising expectation, in particular, if we look at the trend of VAT revenues in the nine-month period, we will notice that this year is the highest rate in terms of budget revenues despite the pandemic.

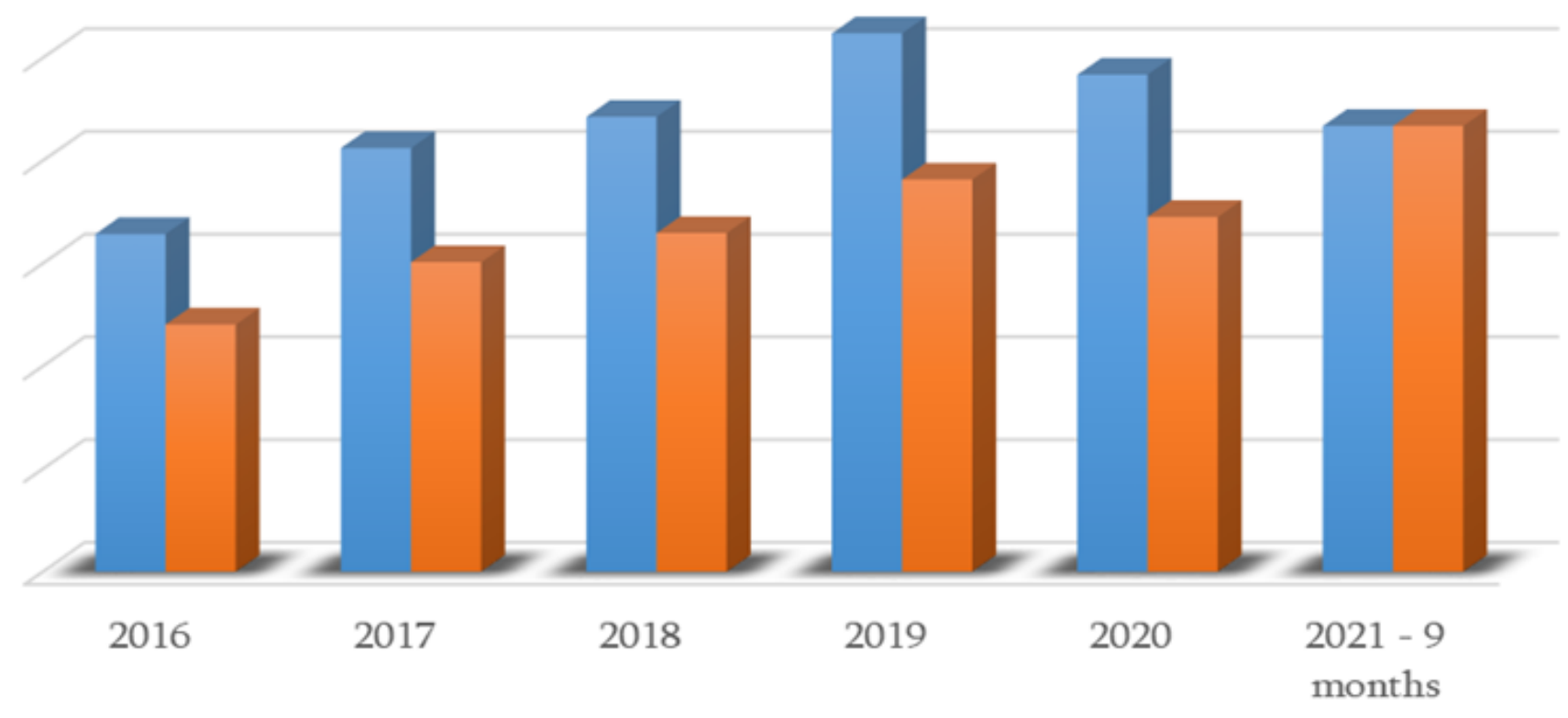

\section{Full year 9 months}

Figure-1. Value Added Tax (VAT) revenues in the budget of Georgia.

Source: Ministry of Finance of Georgia State Treasury (2021).

In general, there are a total of six types of taxes in Georgia, including 5 state taxes - these are: profit tax, income tax, VAT, excise tax, import tax and 1 local - property tax. As mentioned above, value added tax (VAT) is having a significant impact on state budget revenues. In general, if we look at the importance of value added tax (VAT) in terms of total state budget revenues, we will see that it is the most important and any tax reform around it is highly responsible (see Figure N2).

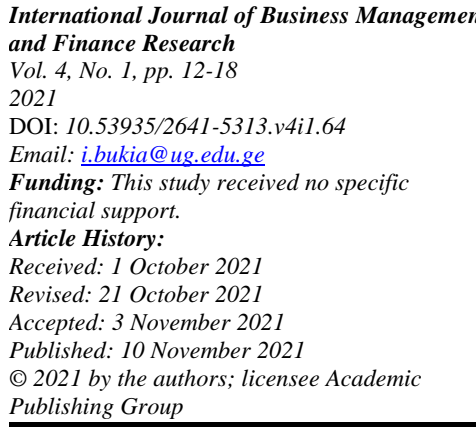




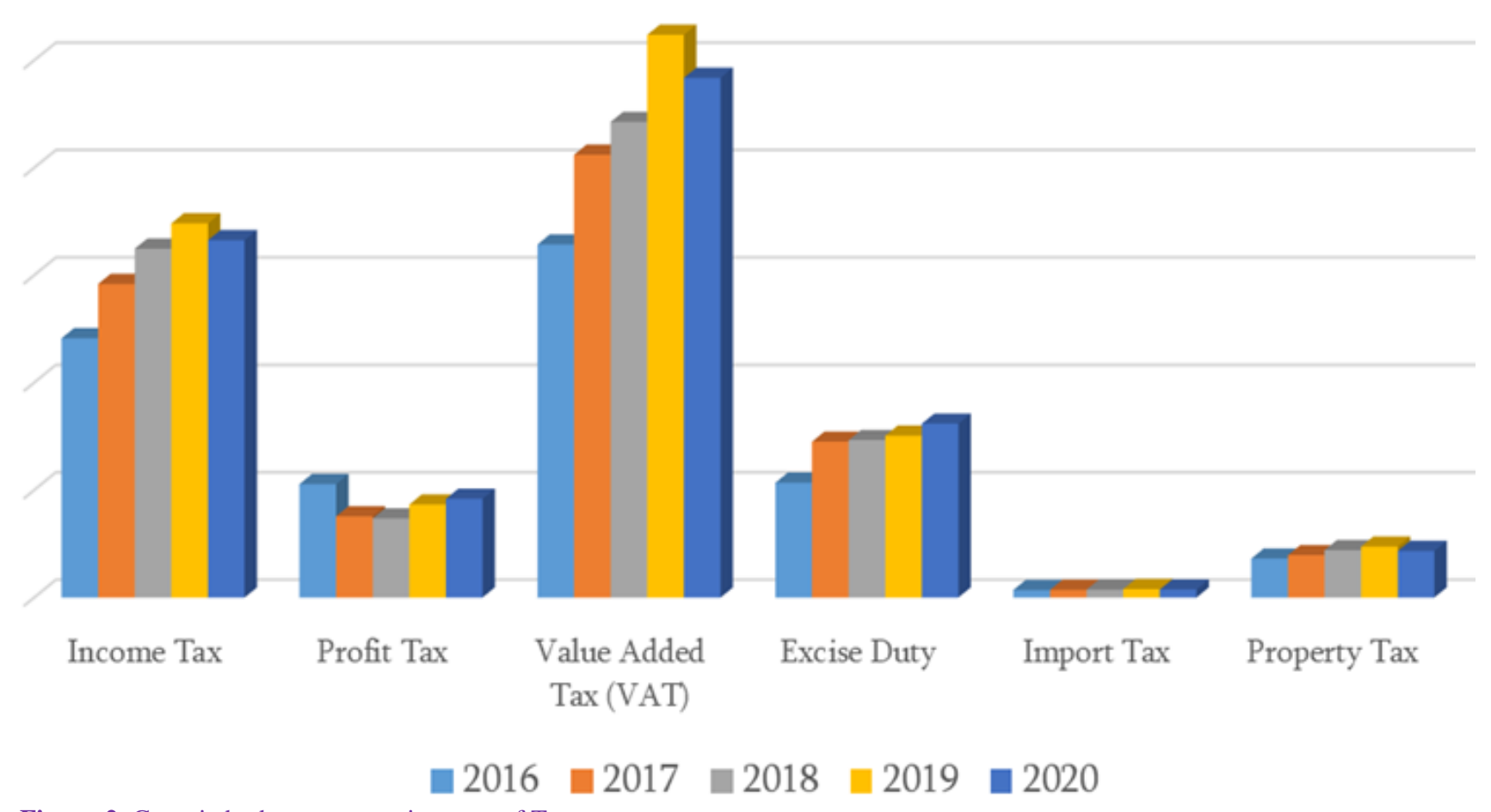

Figure-2. Georgia budget revenues in terms of Taxes.

Source: Ministry of Finance of Georgia State Treasury (2021)

\section{Conclusions}

Part of Georgia's economic policy, in this case the tax policy reforms around value added tax (VAT) can be summarized as follows: The main reform that has changed the tax legislation around the given tax, based on the analysis of the results of budget revenues in recent years is a positive trend, despite considering the entrepreneurial environment delayed due to the pandemic. As for the following reform, which concerns the status of a qualified VAT payer, through which the process of tax administration should be improved and also fraudulent schemes and improper VAT registration and illegal issuance of relevant documents should be managed, it is too early to assess this reform, as in this case we do not have full year data. And the third reform concerning value added tax (VAT), which deals with the service of automatic return of overpayments for a given tax to taxpayers; This is unequivocally positive for entrepreneurs, as evidenced by the results of the survey (which was conducted in the year of the adoption of this reform), as well as the ratio of refunds in 2019-2020. It should also be noted that in order to assess the business environment, the World Bank publishes an annual report based on data from 190 countries, where countries are ranked according to pre-designed indicators according to various indicators, such as: In terms of easy business start-up opportunities; In terms of carrying out various reforms to improve the business environment; Also in terms of simplicity of property registration procedures; Including in terms of time spent on given procedures, in terms of building permits and their quality control, and many more. According to the report - Doing Business 2020, Georgia ranks 7th (score 83.7) among 190 countries around the world, which is one of the signs that the reforms carried out by the state are helping entrepreneurs to reduce bureaucratic procedures and make it easier for them to start a business and develop it. This clearly reflects the country's efforts to improve the entrepreneurial environment (World Bank Group, 2020). The entrepreneurial environment in Georgia is not only favorable for local entrepreneurs, but International Journal Vol. 4. No. 1, pp. 12-18 2021 DOI: $10.53935 / 2641-5313 . v 4 i 1.64$ Email: i.bukia@ug.edu.ge Email: i.bukia@ug.edu.ge Funding: This study, financial support.

Article History:
Received: 1 October 2021

Revised: 21 October 2021

Accepted: 3 November 2021

Published: 10 November 2021

(C) 2021 by the authors; licensee Academic Publishing Group 


\section{References}

Bukia, I. (2019). Expectations and results of tax reforms implemented in Georgia. Saudi Journal of Economics and Finance (SJEF), 3(9), 395-398. Available at: https://doi.org/10.36348/sjef.2019.v03i09.004.

European Commission. (2020). Vat gap report 2020. Retrieved from: https://ec.europa.eu/taxation_customs/vat-gap_en.

Ministry of Finance of Georgia. (2021). Decree №25697 of the head of the revenue service of August 5, 2021 "On Restriction of the Right to Tax Invoices, Subscription / Confirmation of Tax Documents and Subscription of Invoices for Taxpayers in Certain Cases" (as of September 16, 2021).

Ministry of Finance of Georgia State Treasury. (2021). Georgia consolidated budget revenues (without consolidation). 2016-2021 Years. Retrieved from: www.treasury.ge.

Parliament of Georgia. (2010). Tax code of Georgia (As of September 20, 2020).

Parliament of Georgia. (2010). Tax code of Georgia. (As of September 26, 2021).

Revenue Service of Georgia. (2020). Presentation on automatic VAT refund. Retrieved from: https://www.youtube.com/watch?v=ja8RFu6Yobo\&feature=youtu.be (OECD Tax - Youtube Channel).

World Bank Group. (2020). Doing business 2020. Retrieved from: https://www.doingbusiness.org/en/reports/global-reports/doingbusiness-2020. 